\title{
STAT6 expression in T cells, alveolar macrophages and bronchial biopsies of normal and asthmatic subjects
}

\author{
Katsuyuki Tomita ${ }^{1 * \dagger}$, Gaetano Caramori ${ }^{2,3 \dagger}$, Kazuhiro Ito ${ }^{3}$, Hiroyuki Sano ${ }^{1}$, Sam Lim $^{3}$, Timothy Oates ${ }^{3}$, Borja Cosio ${ }^{3}$, \\ K Fan Chung ${ }^{3}$, Yuji Tohda ${ }^{1}$, Peter J Barnes ${ }^{3}$ and lan M Adcock ${ }^{3}$
}

\begin{abstract}
Background: Asthma is characterised by increased numbers of Th2-like cells in the airways and lgE secretion. Generation of Th2 cells requires interleukin (IL)-4 and IL-13 acting through their specific receptors and activating the transcription factor, signal transducer and activator of transcription 6 (STAT6). STAT6 knockout mice fail to produce IgE, airway hyperresponsiveness and bronchoalveolar lavage eosinophilia after allergen sensitisation, suggesting a critical role for STAT6 in allergic responses.

Methods: We have investigated the expression of STAT6 in peripheral blood T-lymphocytes, alveolar macrophages and bronchial biopsies from 17 normal subjects and 18 mild-moderate steroid-naïve stable asthmatic patients.

Results: STAT6 expression was variable and was detected in T-lymphocytes, macrophages and bronchial epithelial cells from all subjects with no difference between normal and stable asthmatic subjects.

Conclusions: STAT6 expression in different cells suggests that it may be important in regulating the expression of not only Th2-like cytokines in T cells of man, but may also regulate STAT-inducible genes in alveolar macrophages and airway epithelial cells.
\end{abstract}

Keywords: Airway epithelial cells, Alveolar macrophages, Asthma, STAT6, T-cells, Th2 cells

\section{Introduction}

Asthma is characterised by chronic airway inflammation, with infiltration of T-lymphocytes, mast cells, eosinophils and monocytes/macrophages. This is associated with the increased expression of several inflammatory proteins, including cytokines, enzymes, receptors and adhesion molecules [1]. The molecular pathways involved in the induction of chronic cytokine expression and recruitment to the airways and activation of inflammatory cells in asthma are not well understood. However, there is increasing recognition that these processes involve increased transcription of inflammatory genes, and that this is regulated by transcription factors [1]. Several transcription factors are involved in asthmatic inflammation including

\footnotetext{
* Correspondence: tom0223@ko-arena.med.kindai.ac.jp

† Contributed equally

'Department of Respiratory Medicine and Allergology, Kinki University

School of Medicine, Osaka, Japan

Full list of author information is available at the end of the article
}

nuclear factor $-\kappa \mathrm{B}(\mathrm{NF}-\kappa \mathrm{B})[2,3]$ and activator protein-1 (AP-1) [4].

CD4+ T helper (Th) cells can be divided into four major subsets termed Th1, Th2, Th17 and Th0 based on the pattern of cytokines they produce. More recently, another two subsets of effector CD4+ Th cells, named Th9 and Th22 cells, have been described, even if their pathophysiological meaning is still unclear $[5,6]$. Th1 cells produce predominantly interferon gamma (IFN $\gamma$ ) and predominantly promote cell-mediated immune responses, whereas Th2 cells, which produce mainly IL-4, IL-5 and IL-13, provide help for some B cell responses. IL-4 and IL-13 in particular are the major inducers of $\mathrm{B}$ cell switching to IgE production, and therefore play a crucial role in allergic reactions involving IgE and mast cells including bronchial asthma [7]. Th0 cells produce both Th1 and Th2 type cytokines and are precursors to Th1 and Th2 cells $[5,6]$. Th17 cells release IL-17A, IL-17F and have been implicated in neutrophils recruitment and more severe disease [8]. Of note, a
C Biomed Central

ㄷ 2012 Tomita et al; licensee BioMed Central Ltd. This is an Open Access article distributed under the terms of the Creative Commons Attribution License (http://creativecommons.org/licenses/by/2.0), which permits unrestricted use, distribution, and reproduction in any medium, provided the original work is properly cited. 
substantial proportion of human Th17 cells produce IFN $\gamma$ in addition to IL-17A, and these cells were named Th17/ Th1 [5].

Recent data suggest the involvement of several transcription factors in the molecular mechanisms by which Th1 and Th2 cells differentially express Th1 and Th2 cytokines genes. For example, differentiation of Th2 cells requires activation of GATA-3 [9] and signal transducer and activator of transcription 6 (STAT6) [10] in mice. Binding of IL-4 and IL-13 with their receptors activates at least two distinct signal transduction pathways, which regulate transcription of specific STAT6-responsive genes. One pathway is associated with the activation of Janus kinase (JAK) 1, 2 and 3. JAK1-3 kinases can, in turn, phosphorylate STAT6 at tyrosine 641, which subsequently forms biologically active homodimers that move from the cytoplasm to the nucleus and regulate transcription of specific STAT6-responsive genes [11]. Generation of Th2-like cells and IgE secretion by IL-4 and IL-13 are mediated by STAT6 in mice [12]. In fact, STAT6 knockout mice have no response to IL-4 and IL-13, do not develop Th2 cells in response to IL-4, fail to produce IgE, airway hyperresponsiveness and bronchoalveolar lavage eosinophilia following allergen sensitisation [13]. This demonstrates the critical role of the STAT6 pathway in allergic responses in mice [14].

Previous data investigating the localisation of STAT6 in the airways of man has produced divergent results. In two studies STAT6 is present only within infiltrating cells of the nose and bronchial mucosa $[15,16]$, whilst in another study STAT6 is expressed predominantly within the bronchial epithelium of mild asthmatic subjects [17].

In order to confirm the site of STAT6-responsive gene expression and activation we have investigated the expression of STAT6 and phosphorylated (activated) STAT6 proteins in peripheral venous blood T cells, alveolar macrophages and bronchial biopsies of normal and asthmatic subjects using Western blotting and immunolocalisation.

\section{Materials and methods Patients}

Eighteen mild-moderate asthmatic patients who fulfil the American Thoracic Society Criteria for asthma [18] and 17 age and sex-matched normal subjects were recruited at the Airway Disease Section of the National Heart and Lung Institute of London. The characteristics of normal and asthmatic subjects are summarised in Table 1. All asthmatic patients demonstrated a $>12 \%$ improvement in forced expiratory volume in one second $\left(\mathrm{FEV}_{1}\right)$ following inhalation of $200 \mu \mathrm{g}$ of salbutamol and airway hyperresponsiveness to methacholine with a provocative concentration of methacholine producing a $20 \%$ fall in $\mathrm{FEV}_{1}$ $\left(\mathrm{PC}_{20}\right)$ of $<8 \mathrm{mg} / \mathrm{ml}$. All asthmatic patients were atopic as defined by two or more positive skin prick tests to common aeroallergens. All asthmatic patients had stable asthma and had not been receiving inhaled or oral glucocorticoid therapy for at least 1 year, and were using only inhaled -agonists drugs intermittently for relief of symptoms. Current smokers or ex-smokers of more than five pack years and patients with $\mathrm{FEV}_{1}<75 \%$ predicted were excluded. All normal subjects had normal lung function, negative skin prick tests to common allergens (except one subject), no bronchial hyperresponsiveness to methacholine $\left(\mathrm{PC}_{20}>32 \mathrm{mg} / \mathrm{ml}\right)$ and were non-smokers. The study was approved by the Royal Brompton Hospital Ethics Committee and all subjects gave their informed consent.

\section{Peripheral venous T cells separation}

Peripheral venous blood $(100 \mathrm{ml})$ was collected (between 08:00 and 09:00 h) into sterile $60 \mathrm{ml}$ syringes containing $5 \mathrm{ml}$ of $100 \%$ ACD (dextroglucose and $\mathrm{Na}_{2} \mathrm{H}$ Citrate solution). Erythrocyte sedimentation was increased by mixing the blood 1:1 with a solution containing $20 \mathrm{ml}$ of Elohaes (Baxter, Thetford, UK) and $5 \mathrm{ml}$ of $10 \% \mathrm{ACD}$ (100\% ACD diluted in saline). After sedimentation for 60 minutes at room temperature the plasma fraction was layered on Ficoll Paque (Amersham Pharmacia Biotech, Little Chalfont, UK) and after density gradient centrifugation, mononuclear cells (PBMCs) were isolated. Following isolation of PBMCs, T cells were isolated by negative selection of pan $T$ cells by depletion of $B$ cells, monocytes, NK cells, dendritic cells, early erythroid cells, platelets and basophils using magnetic beads according to the manufacture instructions (Miltenyi Biotec, Bisley, UK), as previously described [19]. In some experiments CCR5+ cells were further isolated from $\mathrm{T}$-cells by immunomagnetic beads and subsequently analyzed for STAT6 expression by immunocytochemistry.

\section{Fibreoptic bronchoscopy, collection and processing of} bronchial biopsies, brushings and bronchoalveolar lavage Normal subjects and asthmatic patients attended the bronchoscopy suite at 8.30 am after having fasted from midnight and were pre-treated with atropine $(0.6 \mathrm{mg} \mathrm{IV})$ and midazolam (5-10 $\mathrm{mg} \mathrm{IV})$. Oxygen (3 $\mathrm{l} / \mathrm{min}$ ) was administered via nasal prongs throughout the procedure and oxygen saturation was monitored with a digital oximeter. Using local anaesthesia with lidocaine (4\%) to the upper airways and larynx, a fiberoptic bronchoscope (Olympus BF10 Key-Med, Southend, UK) was passed through the nasal passages into the trachea. Further lidocaine $(2 \%)$ was sprayed into the lower airways, and four bronchial mucosal biopsy specimens were taken from segmental and subsegmental airways of the right lower and upper lobes using size 19 cupped forceps. Bronchial biopsies for immunohistochemistry were immediately placed in optimal cutting temperature (OCT) embedding 
Table 1 Characteristics of subjects

\begin{tabular}{|c|c|c|c|c|c|c|}
\hline Normals & AGE & SEX & SKIN-TEST & FEV $_{1}(\%$ pred) & FVC (\%pred) & $\mathrm{PC}_{20}(\mathrm{mg} / \mathrm{ml})$ \\
\hline 1 & 38 & M & negative & 110 & 105 & $>32$ \\
\hline 2 & 32 & M & negative & 102 & 108 & $>32$ \\
\hline 3 & 20 & M & negative & 98 & 102 & $>32$ \\
\hline 4 & 23 & M & positive & 87 & 91 & $>32$ \\
\hline 5 & 20 & M & negative & 83 & 85 & $>32$ \\
\hline 6 & 22 & $\mathrm{~F}$ & negative & 112 & 108 & $>32$ \\
\hline 7 & 20 & M & negative & 89 & 110 & $>32$ \\
\hline 8 & 33 & $\mathrm{~F}$ & positive & 92 & 97 & $>32$ \\
\hline 9 & 24 & M & negative & 98 & 106 & $>32$ \\
\hline 10 & 38 & M & negative & 93 & 97 & $>32$ \\
\hline 11 & 22 & $F$ & negative & 85 & 92 & $>32$ \\
\hline 12 & 33 & M & negative & 106 & 104 & $>32$ \\
\hline 13 & 40 & M & negative & 96 & 95 & N/A \\
\hline 14 & 36 & M & negative & 105 & 101 & N/A \\
\hline 15 & 24 & $\mathrm{~F}$ & negative & 98 & 100 & N/A \\
\hline 16 & 39 & $\mathrm{~F}$ & negative & 102 & 103 & N/A \\
\hline 17 & 23 & M & negative & 106 & 107 & N/A \\
\hline Asthmatics & AGE & SEX & SKIN-TEST & $\mathrm{FEV}_{1}$ (\% pred) & FVC (\%pred) & $P C_{20}(\mathrm{mg} / \mathrm{ml})$ \\
\hline 1 & 26 & $\mathrm{~F}$ & positive & 82 & 100 & $\mathrm{~N} / \mathrm{A}$ \\
\hline 2 & 24 & M & positive & 80 & 84 & N/A \\
\hline 3 & 40 & M & positive & 82 & 96 & 1.2 \\
\hline 4 & 27 & F & positive & 108 & 101 & 4.25 \\
\hline 5 & 33 & M & positive & 78 & 97 & 0.78 \\
\hline 6 & 32 & M & positive & 88 & 95 & N/A \\
\hline 7 & 23 & $\mathrm{~F}$ & positive & 70 & 83 & 0.11 \\
\hline 8 & 37 & M & positive & 106 & 100 & N/A \\
\hline 9 & 33 & M & positive & 96 & 102 & 1.14 \\
\hline 10 & 29 & M & positive & 96 & 105 & N/A \\
\hline 11 & 28 & M & positive & 85 & 98 & 0.46 \\
\hline 12 & 27 & $\mathrm{~F}$ & positive & 77 & 96 & 0.36 \\
\hline 13 & 25 & $\mathrm{~F}$ & positive & 84 & 100 & 2.5 \\
\hline 14 & 30 & M & positive & 81 & 90 & N/A \\
\hline 15 & 31 & M & positive & 82 & 92 & 0.25 \\
\hline 16 & 22 & M & N/A & 95 & 97 & 2.32 \\
\hline 17 & 47 & $M$ & N/A & 100 & 102 & 3.48 \\
\hline 18 & 23 & $M$ & N/A & 95 & 99 & 0.54 \\
\hline
\end{tabular}

$\mathrm{FEV}_{1}$, forced expiratory volume in one second; $\mathrm{FVC}$, forced vital capacity. $\mathrm{PC}_{20}$, provocative concentration of methacholine causing a $20 \%$ fall in $\mathrm{FEV}$. $\mathrm{N} / \mathrm{A}=\mathrm{not}$ available

media, then snap frozen in isopentane, pre-cooled with liquid nitrogen, and stored at $-70^{\circ} \mathrm{C}$. Bronchial biopsies for Western blot analysis were immediately placed on ice and processed as described later. All biopsies were frozen within 20 minutes of collection. Six-micron sections were placed on poly-L-lysine coated microscope slides, air dried for 30 minutes then wrapped in aluminium foil and stored at $-70^{\circ} \mathrm{C}$ prior to immunostaining.

Brushing of the airway was performed with a $2 \mathrm{~mm}$ diameter channel cytology brush (Olympus BC-16 C) inserted via the sampling channel of the bronchoscope and rubbed against the epithelial surface. The brush was retracted and retrieved cells dissociated by vortexing in Ham's F12 nutrient medium. This brushing procedure was repeated 8-10 times. Bronchial epithelial cells smears (10,000 cells/slide) were made using a centrifuge (Shandon Cytospin 3, Southend, UK). The cells were air-dried onto the slides and fixed for $10 \mathrm{~min}$ in cold $4 \%$ phosphate-buffered paraformaldehyde solution.

Bronchoalveolar lavage (BAL) was performed from the right middle lobe using warmed $0.9 \% \mathrm{NaCl}$ with 4 successive aliquots of $60 \mathrm{mls}$. Bronchoalveolar lavage fluid was filtered through sterile gauze and centrifuged at $500 \mathrm{~g}$ for 10 minutes. BAL cells were washed twice with sterile 
HBSS. Cytospins were prepared and stained with MayGrunwald stain for differential cell counts. Cells were > $85 \%$ viable as assessed by trypan blue exclusion. Macrophages were purified by adhesion as previously described [19].

\section{Western blot analysis}

Whole cell proteins were extracted from T cells, alveolar macrophages and bronchial biopsies as previously described [19]. In brief, T cells, alveolar macrophages and bronchial biopsies were resuspended with mechanical disruption in 30-100 1 of $1 \times$ reporter lysis buffer (Promega, Southampton, UK) with a protease inhibitors cocktail (Roche Molecular Biochemicals, Lewes, UK) and phosphatase inhibitors (sodium fluoride and activated sodium orthovanadate), immediately frozen to $-70^{\circ} \mathrm{C}$ and subjected to 3 freeze-thaw steps. Particulate matter was removed by centrifugation at $12000 \times g$ for $10 \mathrm{~min}$ at $4{ }^{\circ} \mathrm{C}$. Protein concentration was measured in the supernatant by the Bradford method according to the manufacturer's instructions (Bio-Rad Laboratories, Hemel Hempstead, UK). 30 g/lane of whole-cell proteins were subjected to $8 \%$ SDS-polyacrylamide gel electrophoresis, and transferred to nitrocellulose filters (Hybond-ECL, Amersham Pharmacia Biotech) by blotting. Filters were blocked for 45 minutes at room temperature in trisbuffered saline (TBS), $0.05 \%$ Tween 20, 5\% non-fat dry milk. The filters were then incubated with rabbit antihuman STAT6 antibody (Santa Cruz Biotechnology, Santa Cruz, CA, USA) and rabbit anti-phosphorylated human (Tyr641) STAT6 antibody (New England Biolabs, Hitchin, UK) for $1 \mathrm{~h}$ at room temperature in TBS, $0.05 \%$ Tween 20,5\% non-fat dry milk at dilution of 1:1000. The first antibody is specific for both phosphorylated and non-phosphorylated STAT6, the second antibody detects only pSTAT6 phosphorylated at Tyr641. Neither antibody cross-reacts with other STAT proteins. IL-4 stimulated HeLa cell extracts (New England Biolabs) were used as a positive control. Filters were washed three times in TBS, 0.5\% Tween 20 and after incubated for 45 minutes at room temperature with anti-rabbit antibody conjugated to horseradish peroxidase (Dako, Ely, UK) in TBS, $0.05 \%$ Tween 20 , 5\% non-fat dry milk, at dilution of 1:4000. After further three washes in TBS, 0.05\% Tween 20 visualisation of the immunocomplexes was performed using the ECL as recommended by the manufacturer (Amersham Pharmacia Biotech). As an internal control we reprobed each filter with an anti-human actin antibody (Santa Cruz Biotechnology).

The $43 \mathrm{kDa}$ (actin) or $100 \mathrm{kDa}$ (STAT6 and pSTAT6) bands were quantified using densitometry with Grab-It and GelWorks software (UVP, Cambridge, UK) and expressed as the ratio with the corresponding actin optical density value of the same lane.

\section{Immunohistochemistry for STAT6 in the bronchial biopsies}

Sections were fixed with cold $4 \%$ phosphate-buffered paraformaldehyde solution. The biopsies were washed repeatedly with phosphate-buffered saline (PBS). The sections were treated with $0.1 \%$ saponin in PBS. Endogenous peroxidase activity was blocked by incubating slides in $1 \%$ hydrogen peroxide $\left(\mathrm{H}_{2} \mathrm{O}_{2}\right)$ and $0.02 \%$ sodium azide in PBS for $1 \mathrm{~h}$, followed by washing in PBS. Non-specific labelling was blocked by coating with blocking serum $(0.1 \mathrm{M}$ phosphate buffer containing $1 \%$ bovine serum albumin and $10 \%$ normal swine serum) for $1 \mathrm{~h}$ at room temperature. After washing in PBS the sections were incubated overnight at $4^{\circ} \mathrm{C}$ with a rabbit polyclonal anti-human STAT6 antibody (Santa Cruz Biotechnology) at dilutions of 1:100 of a $200 \mu \mathrm{g} / \mathrm{ml}$ solution.

For the negative control slides, we did not add the respective primary antibody and in some slides normal rabbit non-specific immunoglobulins (Vector Laboratories, Orton Southgate, UK) were used at the same protein concentration as the primary antibody. After overnight incubation and repeated washing steps with PBS, the sections were subsequently incubated with anti-rabbit biotinylated antibody (1:200 dilution; Dako) for 45 minutes at room temperature. After further washing the sections were subsequently incubated with avidin-horseradish peroxidase (1:200 dilution; Dako) for 45 minutes at room temperature. Slides were then incubated with chromogen-fast diaminobenzidine for 5 minutes, after which they were counterstained in hematoxylin and mounted on mounting medium (DPX).

\section{Quantification}

Counts of positive cells were made on all biopsy sections, and were divided according to whether the positive cells were in the airway epithelium or beneath the epithelium to a depth of $175 \mu \mathrm{m}$. Counts were made only in areas of intact epithelium. For STAT6 proteins, the number of positive cells was expressed as a percentage of nucleated cells in the epithelium and in the subepithelium in at least 4 fields at $x 400$ magnification. For the inflammatory cells, the number of positive cells was expressed as the number per field. For the epithelium, one field was defined as a length of $175 \mu \mathrm{m}$, and for the subepithelium one field was defined as an area of $175 \mu \mathrm{m}^{2}$. At least four fields were counted for each subject for the epithelium and subepithelium. An experienced observer made all counts unaware of the clinical status or the origin of the sections.

\section{Immunocytochemical staining for STAT6 in T cells}

Cytospins of $\mathrm{T}$ cells were fixed with cold $4 \%$ phosphatebuffered paraformaldehyde solution. Cytospins were washed repeatedly with PBS. Endogenous peroxidase activity was blocked by incubating slides in 3\% hydrogen 
peroxide $\left(\mathrm{H}_{2} \mathrm{O}_{2}\right)$ in methanol for $1 \mathrm{~h}$, followed by washing in PBS. Non-specific labelling was blocked by coating with blocking serum (5\% normal goat serum) for 20 minutes at room temperature. The cell membranes were permeabilised adding to the blocking serum $0.5 \%$ Triton $\mathrm{X}-100$. After washing in PBS the cells were incubated for $1 \mathrm{~h}$ with rabbit polyclonal anti-human STAT6 antibody (Santa Cruz Biotechnology) at dilutions of 1:50 of a $200 \mu \mathrm{g} / \mathrm{ml}$ solution.

For the negative control slides, we did not add the respective primary antibody and in some slides normal rabbit non-specific immunoglobulins (http://www.scbt. com) were used at the same protein concentration as the primary antibody. After incubation and repeated washing steps with PBS, the cells were subsequently incubated with anti-rabbit biotinylated antibody (Vector Laboratories) for 30 minutes at room temperature. After further washing the sections were subsequently incubated with $A B C$ reagent (Vector Laboratories) for 30 minutes at room temperature. Slides were then incubated with chromogen-fast diaminobenzidine for 5 minutes after which they were counterstained in haematoxylin and mounted on permanent mounting medium (DPX).

\section{Statistical analysis}

Data are presented as mean \pm SD. Differences between normal and asthmatic subjects were assessed with the Mann-Whitney $U$-test, and a value of $p<0.05$ was taken as significant.

\section{Results}

\section{T-Lymphocytes}

Western blot analysis of isolated T cells showed no significant difference in the expression of STAT6 in steroidnaive asthmatic patients compared to normal subjects $(0.73 \pm 0.18$ vs $0.72 \pm 0.22$; not significant) (Figure 1$)$. There was no expression of pSTAT6 in either normal subjects or asthmatic patients (Figure 1C) although a pSTAT6 band was detected in the positive control lane. Immunostaining indicated that STAT6 expression was mainly but not exclusively confined to the cytoplasm. STAT6 was found in the nucleus of some T cells isolated from both normal and mild-moderate steroid-naïve asthmatic subjects (Figure 2A). Using the chemokine receptor CCR5 as a marker for Th1 cells [20] we examined the expression of STAT6 in CCR5+ and CCR5- cells isolated from freshly isolated human T-cells. STAT6 was highly expressed and localised predominantly within the nucleus of CCR5-(Th2-like) cells compared with minimal cytoplasmic expression within CCR5+ (Th1-like) cells (Figure 2B $\& 2 C)$. There was no difference in the number of CCR5+ and CCR5- cells between normal and asthmatic subjects. The pSTAT6 antibody is not able to detect protein by

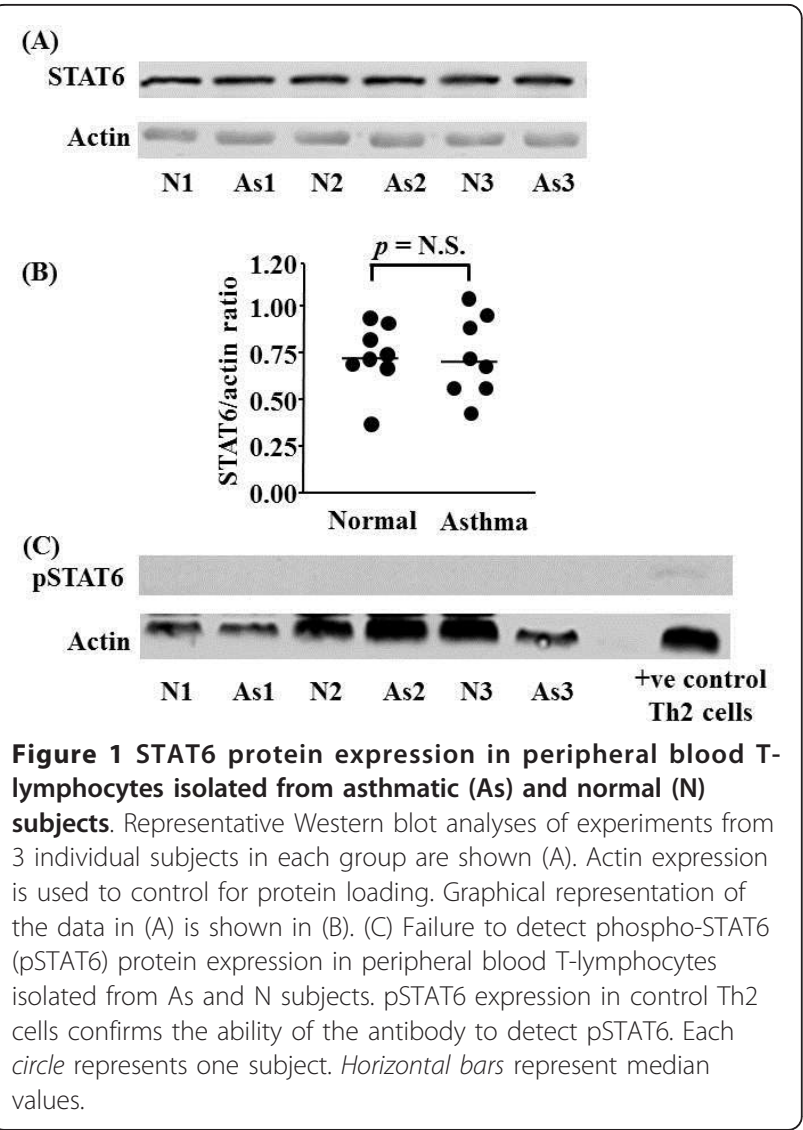

immunocytochemistry or immunohistochemistry (data not shown).

\section{Alveolar macrophages}

Using Western blot analysis in alveolar macrophages we observed the presence of STAT6 protein, both in normal subjects and in asthmatic patients. There was no difference in the expression of STAT6 protein between the two groups of subjects $(0.65 \pm 0.16$ vs $0.65 \pm 0.16$; not significant) (Figure 3). There was no discernable expression of pSTAT6 in either normal subjects or asthmatic patients using Western blotting (Figure $3 \mathrm{C}$ ) although a p-STAT6 band was detected in the positive control lane.

Representative Western blot analyses of experiments from 3 individual subjects in each group are shown (A). Actin expression is used to control for protein loading. Graphical representation of the data in (A) is shown in B. (C) Failure to detect phospho-STAT6 (pSTAT6) protein expression in alveolar macrophages isolated from As and N subjects. pSTAT6 expression in control IL-4 stimulated HeLa cells confirms the ability of the antibody to detect pSTAT6. Each circle represents one subject. Horizontal bars represent median values 


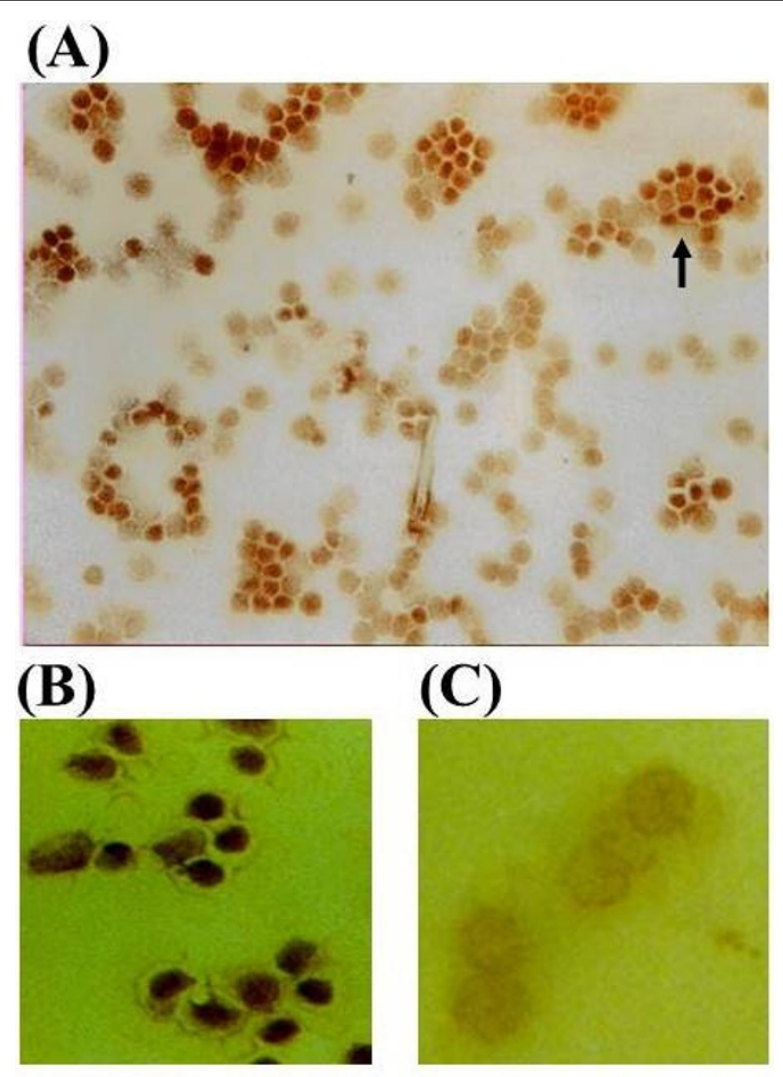

Figure 2 Representative immunocytochemical staining for STAT6 in T-lymphocytes (A), CCR5- (B) and CCR5+ cells (C). STAT6 is localised predominantly to the cytoplasm. However, in a small subset of T cells nuclear localisation of STAT6 can be detected. STAT6 is localised predominantly to the nucleus of CCR5- but not CCR5+ cells.

\section{Bronchial biopsies}

Immunohistochemical staining (Figure 4) shows that most of the cells staining for the STAT6 protein are bronchial epithelial cells in both normal subjects and asthmatic patients. However, there were some STAT6 positive cells in the lamina propria both in normal and in asthmatic patients (Figure 4). Western blot analysis indicated that there was variable expression of STAT6 but no significant difference in the expression of STAT6 protein (normalised for the actin ratio) in bronchial biopsies of normal subjects compared to asthmatic subjects $(0.82 \pm 0.5$ vs $0.89 \pm 0.28$; not significant) (Figure 4). Using Western blot analysis we were unable to detect pSTAT6 expression in bronchial biopsies of normal subjects compared with asthmatic patients (Figure 5C) although a p-STAT6 band was detected in the positive control lane.

\section{Discussion}

$\mathrm{T}$ cells isolated from peripheral venous blood of normal subjects and steroid-naïve stable asthmatic patients expressed STAT6 protein. However there was no increased expression in $\mathrm{T}$ cells from asthmatic patients compared to normal subject or in its activation. This is in accordance with a previous study that found similar levels of STAT6 in PBMCs from normal subjects and patients with extrinsic asthma [21]. This suggests that either there is no increase in activated Th2 cells in the blood in the predominantly mild, stable, asthmatic patients studied here or that STAT6 activation is not important for this process. This further suggests that Th2-like gene regulation in man may be controlled, at least in part by the expression of proteins distinct from those predicted by studies in human cell lines or in the mouse. For example, many animal and human in vitro studies suggest that GATA-3 plays an important role in the differentiation of Th2 cells in conjunction with other transcription factors such as nuclear factor of activated T cells (NF-AT)c/B, cMaf and STAT6 $[9,22]$.

In both normal subjects and asthmatic patients, alveolar macrophages and bronchial epithelial cells also expressed STAT6 proteins. The predominant sites of STAT6 expression in bronchial biopsies are epithelial cells in all subjects. These results are in contrast to two previous studies using immunohistochemistry in which the authors were unable to find any STAT6 immunoreactivity in nasal [15] and bronchial epithelial cells [16] but 


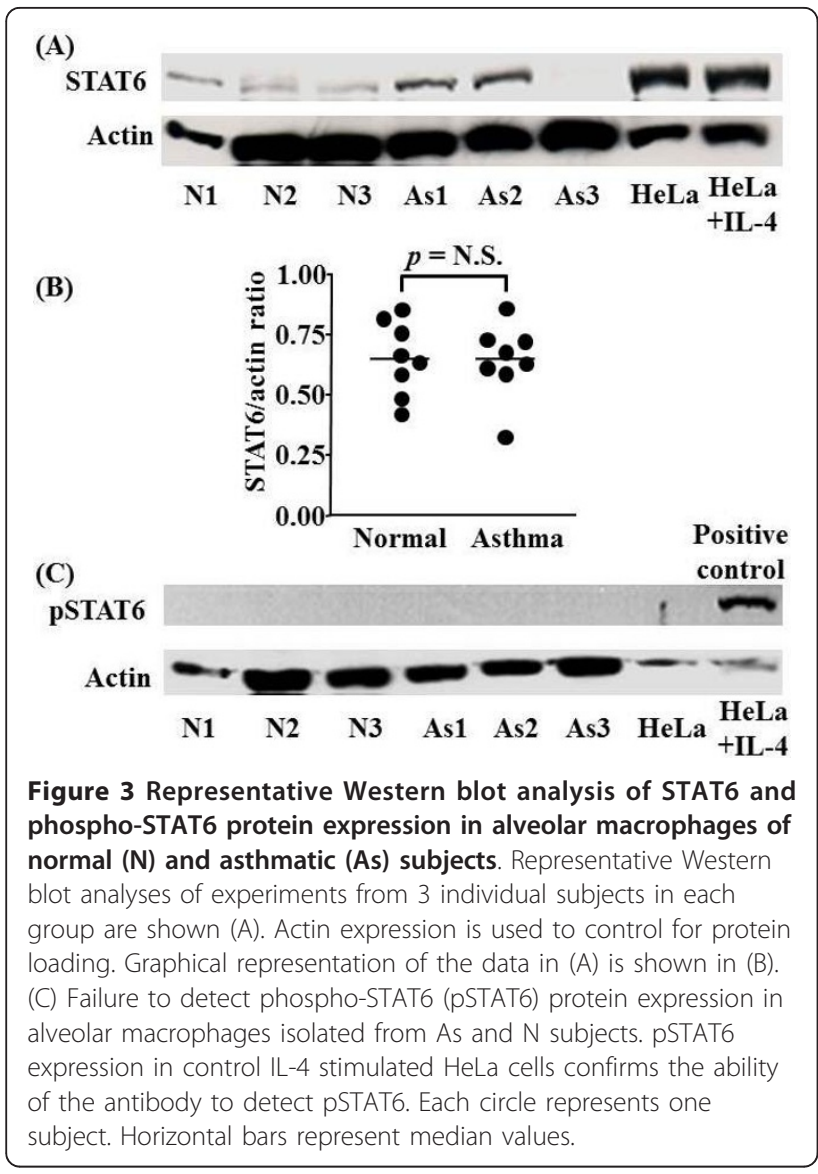

detected STAT6 localised to the nuclei of some infiltrating cells.

This discrepancy may depend upon differential expression of STAT6 in epithelial cells from upper and lower airways since we found similar results with the two different antibodies by Western blottings. However, we did not use the same STAT6 antibodies (two mouse monoclonals respectively from Transduction Laboratories and Santa Cruz) as Ghaffer and colleagues [15] and Christodoulopoulos and colleagues [16] for immunostaining and their sensitivity may differ. However, this is unlikely to account for the different site of expression seen in bronchial airways. Another study using immunohistochemistry with the same antibody as used here has also shown that the bronchial epithelium is the major site of STAT6 expression [23]. In addition, they also reported no difference in the site of expression between asthmatic and normal control subjects [17].

The presence of STAT6 immunoreactive cells with nuclear localisation of STAT6 in the nasal mucosa of atopic allergic rhinitis may be the result of a selective accumulation of Th2 cells in this disease. This is in accordance with the presence of a minority of $\mathrm{T}$ cells with nuclear localisation of STAT6 demonstrated by immunostaining

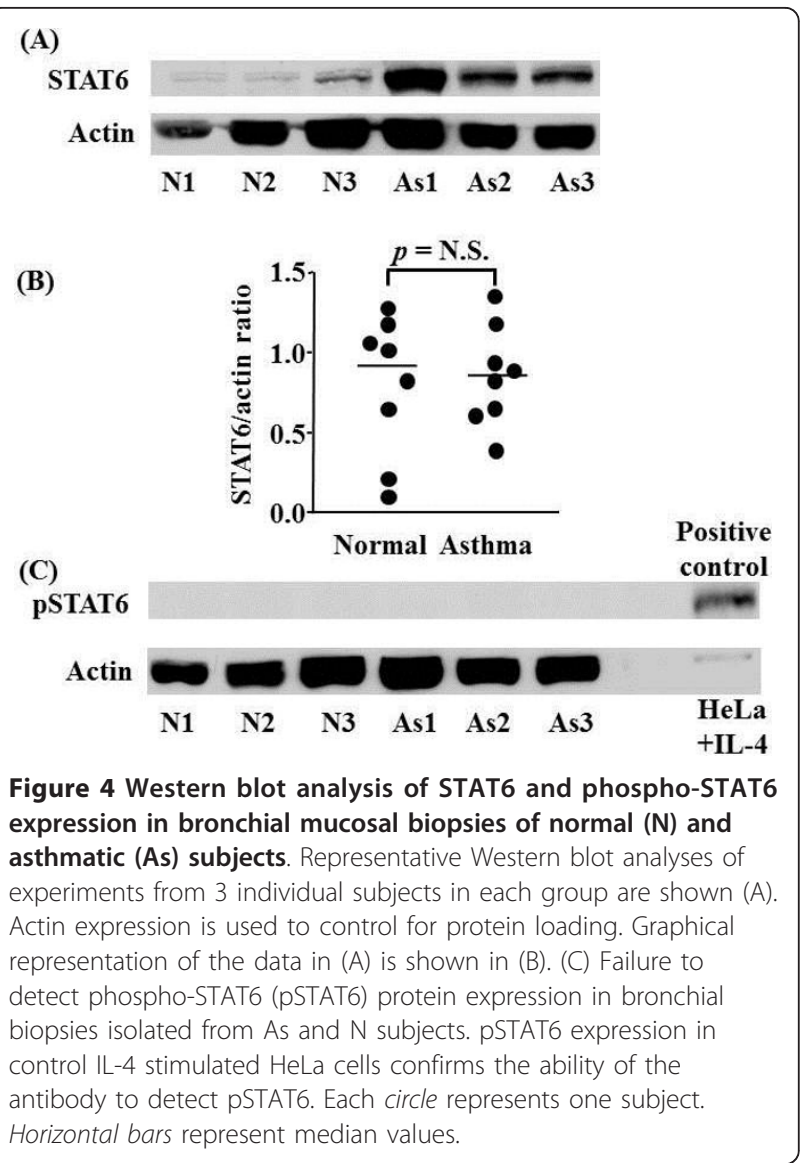

and with the results of a previous study that showed no activation of STAT6 in PBMCs from patients with acute asthma [21].

Human bronchial epithelial cells and alveolar macrophages express IL-4R complex [24], respond to IL-4 and IL-13 and produce cytokines such as GM-CSF and eotaxin which contain STAT6-binding sites in the regulatory sequences of their genes [25-30]. In animal models of allergic asthma, blockade of IL-13 markedly inhibits allergen-induced airway hyperresponsiveness, mucus production and eosinophilia [31]. Furthermore, IL-13 delivery to the airway causes all of these effects [31]. Mice lacking STAT6 gene are protected from all pulmonary effects of IL-13 [31]. Reconstitution of STAT6 only in bronchial epithelial cells is sufficient for IL-13-induced airway hyperresponsiveness and mucus production in the absence of inflammation, fibrosis or other lung pathology [31]. These results demonstrate the importance of direct effects of IL-13 and STAT6 on epithelial cells in causing two central features of bronchial asthma [31].

Interestingly, induction of inducible nitric oxide synthase (iNOS) in both bronchial epithelial cells and alveolar macrophages involves IL-4 and STAT6 [23,32]. These data suggest that STAT6, which is key components of 

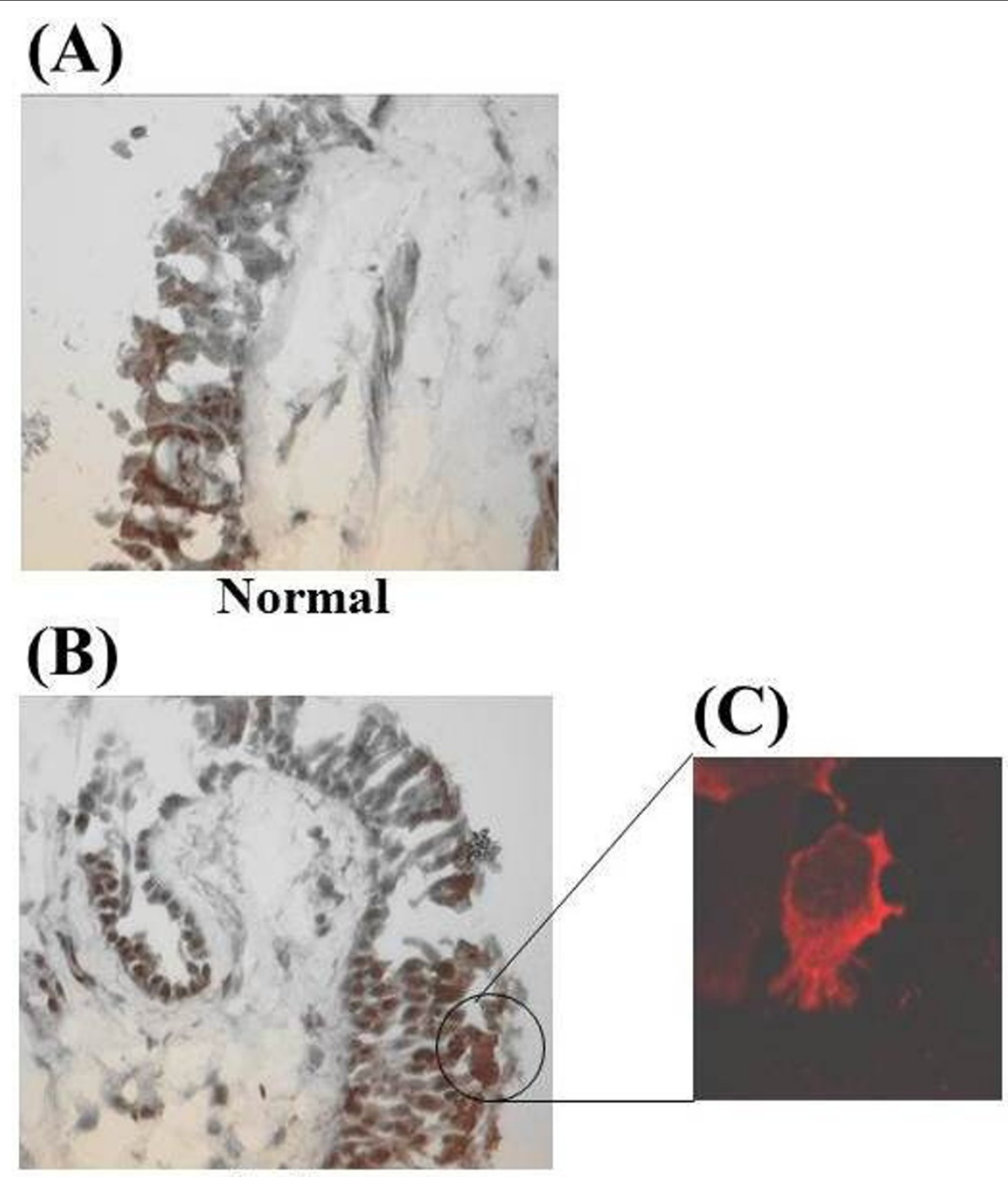

\section{Asthma}

Figure 5 Immunohistochemical staining for STAT6 protein in bronchial mucosal biopsies of normal (A) and asthmatic (B) subject, and representative immunofluorescence staining for STAT6 in bronchial epithelial cells of an asthmatic subject (C).It indicates that STAT6 is localised predominantly to the cytoplasm in bronchial cells of an asthmatic subject.

signals via IL-4 and IL-13, may potentially play an important role in modulating inflammatory gene expression in alveolar macrophages and bronchial epithelial cells. However, our result demonstrated the same level of STAT6 in T-lymphocytes, macrophages and bronchial epithelial cells from all subjects with no difference between normal and asthmatic subjects. There are some potential explanations for these results. Firstly, the process of STAT-6 translocation from cytoplasm into nucleus is dependent of other signals, such as Src kinase and phospholipase $\mathrm{C}$ activity $[33,34]$. The existence of cytoplasmic STAT6 might denote that other signals such as oxidative stress, which may induce phospholipase $\mathrm{C}$ activity, is required for the translocation of STAT6 into nucleus. Secondly, for IL-4/
IL-13-mediated pathway activation, there is also a STAT6independent process such as a acidic mammalian chitinase [35]. In this paper, STAT6 activation was assessed using immunoblotting. Additional data will be required to assess STAT6 activation by quantative ELISA for identifying transcription factor binding to DNA and chromatin immunoprecipitation assay.

In the last decade many clinical studies have examined the effect of blocking Th2 activity in human asthma. Overall, these studies have proved disappointing in that as a group mild-moderate asthmatics, similar to those studied here, did not respond clinically to drugs targeting IL-4, IL-5 and IL-13 [36-38]. This raises the possibility that the underlying concept of asthma being a 
Th2-driven hyper-eosinophilic disease which has been developed in animal models is not reflected in human disease except in small subsets of patients with selected asthmatic phenotypes [36,37]. This further highlights the need for more translational research into asthma mechanisms in man if common drivers of disease in human asthma are to be determined.

In summary, $\mathrm{T}$ cells from normal subjects and mildmoderate steroid-naïve asthmatic patients in stable phase asthmatics express similar levels of STAT6 protein within each subcellular compartment. Alveolar macrophages and bronchial epithelial cells also express STAT6 proteins with equal expression in normal subjects and asthmatic patients. STAT6 may be important in regulating the expression of Th2-like cytokines in alveolar macrophages and bronchial epithelial cells in addition to $\mathrm{T}$ cells in man. Further studies with large number of participants are needed to characterise fully the role of the STAT6 proteins in the regulation of gene expression in these cell types and their potential role in the pathogenesis of asthma, because asthma has various phenotypes. A previous study suggested that treatment with topical glucocorticoids can reduce the number of CD3+/STAT6 immunoreactive cells in nasal mucosa [15]. However at present the ability of glucocorticoids to target STAT6 action in the lower airways is unknown and may determine whether inhibition of STAT6 activity may be a new therapeutic target for anti-asthma drugs.

\section{Acknowledgements}

The Authors are indebted to Dr. Francesco Sinigaglia (Bioxell, Milan, Italy) for kindly providing us his human Th2 cell lines. This work was funded by Associazione per la Ricerca e la Cura dell'Asma (ARCA, Padova, Italy), Clinical Research Committee (Royal Brompton Hospital), MRC and GlaxoSmithKline (UK). Gaetano Caramori was funded by a European Respiratory Society Fellowship.

\section{Author details}

${ }^{1}$ Department of Respiratory Medicine and Allergology, Kinki University School of Medicine, Osaka, Japan. ${ }^{2}$ Section of Respiratory Diseases, Department of Clinical and Experimental Medicine, Università di Ferrara, Ferrara, Italy. ${ }^{3}$ Airway Disease Section, National Heart and Lung Institute, Imperial College of London, London, UK.

\section{Authors' contributions}

KT and GC: Conceived \& designed the study \& drafted the manuscript. IK, SL and HS: Helped design \& participated in the clinical studies \& drafting the manuscript. TQ: Participated in the immunohistochemical studies. SL and BC: Helped in clinical samples. KF, YT, PB, and IA: Participated in the study design \& coordination and drafting of the manuscript. All authors read and approved the final manuscript.

\section{Competing interests}

The authors declare that they have no competing interests.

Received: 9 July 2011 Accepted: 9 March 2012 Published: 9 March 2012

\section{References}

1. Barnes PJ, Chung KF, Page CP: Inflammatory mediators of asthma: an update. Pharmacol Rev 1998, 50:515-596.
2. Hart L, Lim S, Adcock I, Barnes PJ, Chung KF: Effects of inhaled corticosteroid therapy on expression and DNA-binding activity of nuclear factor kappaB in asthma. Am J Respir Crit Care Med 2000, 161:224-231.

3. Hart LA, Krishnan VL, Adcock IM, Barnes PJ, Chung KF: Activation and localization of transcription factor, nuclear factor-kappaB, in asthma. Am J Respir Crit Care Med 1998, 158:1585-1592.

4. Demoly P, Basset SN, Chanez P, et al: c-fos proto-oncogene expression in bronchial biopsies of asthmatics. Am J Respir Cell Mol Biol 1992, 7:128-133.

5. Annunziato F, Galli G, Cosmi L, Romagnani P, Manetti R, Maggi E, Romagnani S: Molecules associated with human Th1 or Th2 cells. Eur Cytokine Netw 1998, 9:12-16.

6. Annunziato F, Romagnani S: Heterogeneity of human effector CD4+ T cells. Arthritis Res Ther 2009, 11:257-264.

7. Bacharier LB, Geha RS: Molecular mechanisms of IgE regulation. J Allergy Clin Immunol 2000, 105(Suppl):547-558.

8. Doe C, Bafadhel M, Siddiqui $S$, et al: Expression of the T helper 17associated cytokines IL-17A and IL-17 F in asthma and COPD. Chest 2010, 138:1140-1147.

9. Ray A, Cohn L: Th2 cells and GATA-3 in asthma: new insights into the regulation of airway inflammation. J Clin Invest 1999, 104:985-993.

10. Kurata H, Lee HJ, O'Garra A, Arai N: Ectopic expression of activated Stat6 induces the expression of Th2-specific cytokines and transcription factors in developing Th1 cells. Immunity 1999, 11:677-688.

11. Schindler C, Strehlow I: Cytokines and STAT signaling. Adv Pharmacol 2000, 47:113-174.

12. Daniel C, Salvekar A, Schindler U: A gain-of-function mutation in STAT6. J Biol Chem 2000, 275:14255-14259.

13. Akira S: Functional roles of STAT family proteins: lessons from knockout mice. Stem Cells 1999, 17:138-146.

14. Tomkinson A, Kanehiro A, Rabinovitch N, Joetham A, Cieslewicz G, Gelfand EW: The failure of STAT6-deficient mice to develop airway eosinophilia and airway hyperresponsiveness is overcome by interleukin-5. Am J Respir Crit Care Med 1999, 160:1283-1291.

15. Ghaffar O, Christodoulopoulos P, Lamkhioued B, et al: In vivo expression of signal transducer and activator of transcription factor 6 (STAT6) in nasal mucosa from atopic allergic rhinitis: effect of topical corticosteroids. Clin Exp Allergy 2000, 30:86-93.

16. Christodoulopoulos P, Cameron L, Nakamura Y, et al: TH2 cytokineassociated transcription factors in atopic and nonatopic asthma: evidence for differential signal transducer and activator of transcription 6 expression. J Allergy Clin Immunol 2001, 107:586-591.

17. Mullings RE, Wilson SJ, Puddicombe SM, et al: Signal transducer and activator of transcription 6 (STAT-6) expression and function in asthmatic bronchial epithelium. J Allergy Clin Immunol 2001, 108:832-838

18. Standards for the diagnosis and care of patients with chronic obstructive pulmonary disease (COPD) and asthma. This official statement of the American Thoracic Society was adopted by the ATS Board of Directors, November 1986. Am Rev Respir Dis 1987, 136:225-244.

19. Ito K, Lim S, Caramori G, Chung KF, Barnes PJ, Adcock IM: Cigarette smoking reduces histone deacetylase 2 expression, enhances cytokine expression, and inhibits glucocorticoid actions in alveolar macrophages. FASEB J 2001, 15:1110-1112.

20. Di Stefano A, Capelli A, Lusuardi M, et al: Decreased T-lymphocyte infiltration in bronchial biopsies of subjects with severe chronic obstructive pulmonary disease. Clin Exp Allergy 2001, 31:893-902

21. Miller RL, Eppinger TM, McConnell D, Cunningham-Rundles C, Rothman P: Analysis of cytokine signaling in patients with extrinsic asthma and hyperimmunoglobulin E. J Allergy Clin Immunol 1998, 102:503-511.

22. Caramori G, Lim S, Ito $K$, et al: Expression of GATA family of transcription factors in T-cells, monocytes and bronchial biopsies. Eur Respir J 2001, 18:466-473.

23. Guo FH, Uetani K, Haque SJ, et al: Interferon gamma and interleukin 4 stimulate prolonged expression of inducible nitric oxide synthase in human airway epithelium through synthesis of soluble mediators. J Clin Invest 1997, 100:829-838.

24. van der Velden $\mathrm{VH}$, Naber BA, Wierenga-Wolf AF, et al: Interleukin 4 receptors on human bronchial epithelial cells. An in vivo and in vitro analysis of expression and function. Cytokine 1998, 10:803-813.

25. Bonecchi R, Facchetti F, Dusi $S$, et al: Induction of functional IL-8 receptors by IL-4 and IL-13 in human monocytes. J Immunol 2000, 164:3862-3869. 
26. Hart PH, Bonder CS, Balogh J, Dickensheets HL, Donnelly RP, Finlay-Jones JJ: Differential responses of human monocytes and macrophages to IL-4 and IL-13. J Leukoc Biol 1999, 66:575-578.

27. Matsukura S, Stellato C, Plitt JR, et al: Activation of eotaxin gene transcription by NF-kappa B and STAT6 in human airway epithelial cells. J Immunol 1999, 163:6876-6883.

28. Striz I, Mio T, Adachi Y, Robbins RA, Romberger DJ, Rennard SI: IL-4 and IL13 stimulate human bronchial epithelial cells to release IL-8. Inflammation 1999, 23:545-555.

29. Striz I, Mio T, Adachi Y, Heires P, et al: IL-4 induces ICAM-1 expression in human bronchial epithelial cells and potentiates TNF-alpha. Am J Physiol 1999, 277:L58-L64.

30. Matsukura S, Stellato C, Georas SN, et al: Interleukin-13 upregulates eotaxin expression in airway epithelial cells by a STAT6-dependent mechanism. Am J Respir Cell Mol Biol 2001, 24:755-761.

31. Kuperman DA, Huang $X$, Koth $L L$, et al: Direct effects of interleukin-13 on epithelial cells cause airway hyperreactivity and mucus overproduction in asthma. Nat Med 2002, 8:885-889.

32. Nemoto $Y$, Otsuka T, Niiro $H$, et al: Differential effects of interleukin-4 and interleukin-10 on nitric oxide production by murine macrophages. Inflamm Res 1999, 48:643-650.

33. Perez-G M, Melo M, Keegan AD, Zamorano J: Aspirin and salicylates inhibit the IL-4- and IL-13-induced activation of STAT6. J Immunol 2002, 168:1428-1434.

34. Zamorano J, Rivas MD, Garcia-Trinidad A, Qu CK, Keegan AD: Phosphatidylcholine-specific phospholipase $\mathrm{C}$ activity is necessary for the activation of STAT6. J Immunol 2003, 171:4203-4209.

35. Zhu Z, Zheng T, Homer RJ, et al: Acidic mammalian chitinase in asthmatic Th2 inflammation and IL-13 pathway activation. Science 2004, 304:1678-1682.

36. Adcock IM, Caramori G, Chung KF: New targets for drug development in asthma. Lancet 2008, 372:1073-1087.

37. Caramori G, Groneberg D, Ito K, Casolari P, Adcock IM, Papi A: New drugs targeting Th2 lymphocytes in asthma. J Occup Environ Med 2008, 3(Suppl 1):6-35.

38. Nguyen TH, Casale TB: Immune modulation for treatment of allergic disease. Immunol Rev 2011, 242:258-271.

doi:10.1186/1476-9255-9-5

Cite this article as: Tomita et al:: STAT6 expression in T cells, alveolar macrophages and bronchial biopsies of normal and asthmatic subjects. Journal of Inflammation 2012 9:5.

\section{Submit your next manuscript to BioMed Central and take full advantage of:}

- Convenient online submission

- Thorough peer review

- No space constraints or color figure charges

- Immediate publication on acceptance

- Inclusion in PubMed, CAS, Scopus and Google Scholar

- Research which is freely available for redistribution

Submit your manuscript at www.biomedcentral.com/submit
Biomed Central 